\title{
Sanitary sewage disinfection with ultraviolet radiation and ultrasound
}

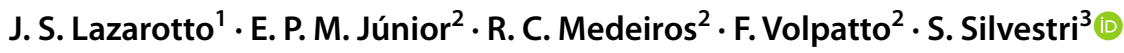

Received: 4 December 2020 / Revised: 29 July 2021 / Accepted: 26 October 2021 / Published online: 8 November 2021

(c) Islamic Azad University (IAU) 2021

\begin{abstract}
Currently, the world is facing a horrible situation due to SARS-CoV-2. Though its RNA was found in wastewater, there are still no studies on RNA contamination detected in sewage. Hence, a possible treatment of sewage is suggested in this work. The disinfection stage is extremely important in the treatment of effluents, minimizing the impacts on the receiving body of water and promoting public health. In this context, the sequential use of ultrasound and ultraviolet radiation, on a bench scale, was investigated as a way to improve the disinfection of anaerobically treated effluents. Two types of treated effluents were tested, by septic tank and anaerobic filter, for which, two ultrasound frequencies, 25 and $40 \mathrm{kHz}$, and four doses of UV, $3.6 ; 9.0 ; 18$ and $36 \mathrm{~mJ} \mathrm{~cm}^{-2}$ were applied. Physicochemical and microbiological parameters were observed for individual and sequential assays. The better quality of the anaerobic filter effluent influenced the performance of both processes, decreasing the concentration of organic load and turbidity, even though a concentration of total coliforms and Escherichia coli occurred in the lowest quality effluent (septic tank). The application of ultrasound has a positive effect on the inactivation of total coliforms and $E$. coli up to $1.0 \mathrm{log}$ and provides better conditions for ultraviolet radiation to be sequentially applied. The UV radiation applied for the septic tank and the anaerobic filter inactivates $2.5 \log$ for total coliforms and $3.5 \log$ for $E$. coli, respectively. It is suggested that the disinfection methods applied in this work to inactivate gram-negative bacteria $(E$. coli) can also be applied to secondary treatment effluents, as well as being better tested for viruses, protozoa, and helminths.
\end{abstract}

Keywords Sequential disinfection $\cdot$ Wastewater treatment $\cdot$ Synergism $\cdot$ Total coliforms $\cdot$ Escherichia coli

\section{Introduction}

Studies indicate that hospitalizations for waterborne diseases are related to inadequate sanitation, such as the low rate of sewage treatment, bringing unnecessary costs to the health care system with potentially preventable diseases (Siqueira et al. 2017; Paiva and Souza 2018).

This statement reflects the size of the challenge for many countries, such as Brazil, with greater perception, which has

Editorial responsibility: Samareh Mirkia.

S. Silvestri

siarasilvestri@gmail.com

1 Graduate Program in Chemical Engineering, Federal University of Santa Maria, Santa Maria, RS, Brazil

2 Department of Engineering and Environmental Technology, Federal University of Santa Maria, Frederico Westphalen, RS, Brazil

3 Graduate Program in Environmental Engineering, Federal University of Santa Maria-UFSM, 1000, Roraima Avenue, Santa Maria, RS 97105-900, Brazil only $53.2 \%$ of collection and $46.3 \%$ of treatment of all the sewage generated in the country (SNIS 2019). Wastewater Treatment Plants were designed primarily to remove organic load, solids, nitrogen and phosphorus, with less focus on the microbiological issue (Kokkinos et al. 2015).

Due to high concentrations of pathogenic organisms, even in treated effluents, the disinfection process is necessary before disposal in receiving bodies and for future reuse (Antoniadis et al. 2007; Zhou et al. 2016). Disinfection aims to reduce the risk of transmission of waterborne diseases, especially when there is direct and indirect contact occurred between human beings and pathogenic microorganisms (WHO 2006; USEPA 2012).

Among alternatives, UV disinfection is perceived as an eco-friendly disinfectant, with high disinfection efficiency, a broad spectrum of inactivation for most pathogens, short hydraulic detention time and easy operation and management (Hijnen et al. 2006; Zhou et al. 2016). However, some factors, such as the low quality of the related effluent, for example, turbidity, color and suspended solids, can affect 
its efficiency (USEPA 1999; Wang et al. 2012; Liang et al. 2013; Farrell et al. 2018).

UV radiation can not only destroy the DNA and RNA structure of microorganisms, forming pyrimidine dimers, but also reactive oxygen species produced by photolysis via oxidative stress could damage the cell membrane (Bosshard et al. 2010; Hallmich and Gehr 2010).

Studies indicate the inactivation of enteric bacteria, viruses, bacterial spores, and protozoan cysts and oocysts as an effective technique for disinfecting wastewater, especially for water reuse and recovery (Oliveira et al. 2008; Liang et al. 2013; O'Flaherty et al. 2017).

In recent years, ultrasound has been used as an advanced oxidation process for wastewater treatment. This is possible due to the production of hydroxyl radicals $\left({ }^{\circ} \mathrm{OH}\right)$ in aqueous solution and the recombination of these radicals in hydrogen peroxide. (Gogate and Kabadi 2009; Joyce et al. 2011; Mahamuni and Adewuyi 2010; Gagol et al. 2018; VázquezLópez et al. 2018; Dehghani et al. 2019). In addition, the incidence of ultrasound radiation generates high-energy bubbles or waves that implode in the reaction medium, a process known as cavitation (Gogate and Kabadi 2009).

Thus, ultrasound radiation can be used to improve the biodegradability of effluents (Gogate and Kabadi 2009; Oller et al. 2011), improve anaerobic digestion and dewater biosolids (Bagluglia et al. 2008; Gogate and Kabadi 2009), in addition to the inactivate pathogenic microorganisms in drinking water and wastewater (Antoniadis et al. 2007; Gibson et al. 2008; Hulsmans et al. 2010; Gao et al. 2014; Naddeo et al. 2014; Zhou et al. 2015, 2016; Abeledo-Lameiro et al. 2018).

Studies show that the simultaneous or sequential combination of more than one disinfectant can enable a synergistic effect, by promoting greater inactivation when compared to the sum of individual inactivations (USEPA 1999; Zhou et al. 2015).

Since ultrasound prevents the agglomeration of particles, it can cause microorganisms to be more exposed to ultraviolet radiation, favoring more efficient disinfection (Joyce et al. 2003; Zhang et al. 2007; Jin et al. 2013; Naddeo et al. 2009; Zhou et al. 2017). This work investigated the effectiveness of US and UV, applied alone and sequentially, to evaluate synergistic effects in killing total coliforms and $E$. coli from onsite wastewater treatment plant effluents.

\section{Materials and methods}

\section{Wastewater effluents and analytical methods}

The experiments were carried out with effluents from the sewage treatment plant located at the Federal University of Santa Maria, Campus Frederico Westphalen, which has a septic tank (STE) followed by an anaerobic filter (AFE).
For disinfection tests, effluent samples were collected from the STE and the AFE. The chemical oxygen demand (COD) was determined by the closed reflux method 5220-D (APHA et al. 2012). The $\mathrm{pH}$ and temperature were analyzed using a pH-meter (mPA-210p). Turbidity was measured through a turbidimeter (DLI 2500, Del Lab®). Total coliforms and Escherichia coli were used to investigate the effectiveness of the disinfection process. Their detection was tested using chromogenic technique with Colilert ${ }^{\circledR}$ media (Idexx Laboratories Inc.).

\section{Lab-scale sonication and UV radiation experiments}

All individual and sequential disinfection tests were carried out in batch. The experiments were realized in two stages. First, individual disinfection tests with ultrasound and ultraviolet radiation were carried out. In the last step, after choosing the exposure time to the US and UV radiation dose, sequential disinfection was performed. All tests were performed in triplicate. A test scheme is shown in Figure S1.

Ultrasound disinfection tests were performed at frequencies of $25 \mathrm{kHz}$ only STE (model USC 2580, UNIQUE®), and of $40 \mathrm{kHz}$ for all effluents (model USC 1600, UNIQUE®). For the tests, $500 \mathrm{~mL}$ of effluent were exposed to ultrasound radiation for 20, 40, 60 and $80 \mathrm{~min}$; therefore, indirectly exposed.

The reactor used for the experiments with ultraviolet radiation, in stainless steel, has dimensions of $8.2 \mathrm{~cm} \times 88.2 \mathrm{~cm}$, with a $30 \mathrm{~W}$ lamp (Osram $\AA$ ) of low pressure of mercury vapor, with emission in the $200-280 \mathrm{~nm}$ range, with a predominance of $254 \mathrm{~nm}$. The lamp had no contact with the liquid. Before the tests, the intensity of the UV radiation emitted by the lamp was measured by actinometry (APHA et al. 2012), with the reactor empty.

Before each test with ultraviolet radiation, the absorbance values of the effluent at $254 \mathrm{~nm}$ (SPECORD ${ }^{\circledR} 50$ PLUSAnalytik Jena) were obtained to calculate the average radiation intensity reaching the liquid. Thus, the necessary times for the application for each UV doses were stipulated; 3.6; $9.0 ; 18$ and $36 \mathrm{~mJ} \mathrm{~cm}^{-2}$. For this, $750 \mathrm{~mL}$ of effluent were used, which resulted in a height of $1 \mathrm{~cm}$ inside the reactor.

For sequential disinfection, two samples of $500 \mathrm{~mL}$ of effluent were submitted to ultrasound and the frequency of $40 \mathrm{kHz}$ was used. STE samples were submitted to US for $80 \mathrm{~min}$, while AFE samples were submitted $60 \mathrm{~min}$. Sequentially, the two $500 \mathrm{~mL}$ samples were mixed and, of these, $750 \mathrm{~mL}$ was subjected to UV, the other $250 \mathrm{~mL}$ were used to perform the US analyses. The STE was subjected to the action of UV radiation, at the applied dose of $36 \mathrm{~mJ} \mathrm{~cm}^{-2}$, and the AFE, at the dose of $18 \mathrm{~mJ} \mathrm{~cm}^{-2}$. The objective was to use a lower dose of UV radiation, in the best quality effluent, to avoid inactivating all bacteria. 


\section{Inactivation efficiency and statistical analysis}

The microorganism inactivation efficiency was calculated using Eq. 1.

Inactivation $=-\log \left(\frac{N}{N o}\right)$

where:

$N$ : represents the number of microorganisms after disinfection;

No: the initial number of microorganisms in the sewage sample before disinfection tests.

The disinfection kinetics model developed by Chick (1908), related to exposure time and frequency (US), was utilized, in relation to the received ultraviolet radiation (UV) dose.

Statistical analysis was performed using the software Statistica 7.0® (Statsoft 2004). The objective was to evaluate the influence of ultrasound, the frequency and time of contact, and the UV dose, in the inactivation of microorganisms, as well as to verify if they presented similar decay. For that, the Analysis of Variance (ANOVA) was performed, with Levene 's test for homogeneity of variances and Tukey' $\mathrm{s}$ test in order to verify differences, which were considered significant when the $p$ - value was $\leq 0.05$.

\section{Results and discussion}

The quality of the effluents used in the disinfection tests, individual and sequential, is shown in Table 1.

\section{US disinfection}

The physicochemical characteristics evaluated- $-\mathrm{pH}$, temperature, turbidity and COD - were shown to be constant for STE, even with longer exposure times to the US (Table S1).

Table 1 Main parameters of the effluents samples

\begin{tabular}{lll}
\hline Parameter & $\begin{array}{l}\text { Septic tank effluent } \\
(\text { STE) }(\text { Mean } \pm \text { SD) }\end{array}$ & $\begin{array}{l}\text { Anaerobic filter } \\
\text { effluent (AFE) } \\
\text { (Mean } \pm \text { SD) }\end{array}$ \\
\hline $\mathrm{pH}$ & $8.20 \pm 0,16$ & $7.49 \pm 0.08$ \\
Temperature $\left({ }^{\circ} \mathrm{C}\right)$ & $24.8 \pm 0,7$ & $24.1 \pm 1.3$ \\
Turbidity $(\mathrm{NTU})$ & $214.8 \pm 18$ & $71.4 \pm 47.2$ \\
$\mathrm{COD}\left(\mathrm{mg} \mathrm{L}^{-1}\right)$ & $558 \pm 98$ & $339 \pm 124$ \\
Escherichia coli & $4.1 \times 10^{6}$ & $4.8 \times 10^{6}$ \\
$(\mathrm{MPN} / 100 \mathrm{~mL})^{*}$ & {$\left[1.0 \times 10^{5}-1.1 \times 10^{7}\right]$} & {$\left[6.9 \times 10^{5}-1.9 \times 10^{7}\right]$} \\
Total coliforms & $1.1 \times 10^{7}$ & $1.7 \times 10^{7}$ \\
$(\mathrm{MPN} / 100 \mathrm{~mL})^{*}$ & {$\left[1.0 \times 10^{5}-6.6 \times 10^{7}\right]$} & {$\left[9.9 \times 10^{6}-3.1 \times 10^{7}\right]$} \\
\hline
\end{tabular}

*Arithmetic mean [min-max]
However, it can be observed that ultrasound $(40 \mathrm{kHz})$ managed to affect the AFE, due to the increase in temperature and turbidity, proportional to the exposure time, despite not showing any statistical difference. The increase in temperature is attributed to the waves generated during the cavitation process (Oliveira et al. 2008).

The effluent matrix plays a decisive role in disinfection, since organic compounds can compete with the hydroxyl radicals formed by cavitation (Antoniadis et al. 2007; Zupanc et al. 2019). Gibson et al. (2009) found that ultrasonic waves have better effects-breaking down wastewater particles-for larger particles (90-250 $\mathrm{mm}$ in diameter), when compared to the smaller ones $(38-63 \mathrm{~mm}$ in diameter). They also report that the percentage of particle breaks increased linearly with the logarithmic increase in the energy density of the ultrasound.

Regarding the microbiological part, the inactivation of the indicators can be seen in Fig. 1, for the different frequencies and exposure times, for the two effluents.

For STE, in both frequencies, there was a decrease in the concentration of the two indicator microorganisms of approximately $1 \log$ (90\% of inactivation), in the time of 80 min of radiation, as can be seen in Fig. $2 \mathrm{~A}$ and B for $25 \mathrm{kHz}$ and $40 \mathrm{kHz}$, respectively. There were no significant differences in terms of contact time and type of microorganism studied, due to the high standard deviation values (Tukey test, $p>0.05$ ). This may have been recurrent due to the heterogeneity of the physical-chemical composition of the effluent between the repetitions.

In the application of ultrasound in AFE, decreases in inactivation were observed at 40 and $60 \mathrm{~min}$ (Fig. 2C). The breakdown of particles and bacterial clusters is assumed due to ultrasound and the consequent "release" of microorganisms to the liquid medium (Blume and Neis 2004; Hulsmans et al. 2010). Thus, at $80 \mathrm{~min}$, there is almost $1 \log$ of inactivation of total coliforms, as already reported to the STE.

Although AFE has less turbidity compared to STE, it presented solids that are easier to break by ultrasound, causing a fast release of microorganisms and consequent lower efficiency in the intermediate times of 40 and $60 \mathrm{~min}$ (Ayyildiz et al. 2011).

The ultrasound process is based on disturbances in the liquid that can combine in effects: mechanical (turbulence, circulation currents and shear stress); chemical (generation of hydroxyl radicals, hydrogen peroxide, etc.); physical (high temperature and pressure conditions); combined effects (when used in combination with chemical treatments, such as chlorine, hydrogen peroxide or ozone, for example) in which a large pressure gradient intensifies the penetration of chemical oxidants through the microbial cell membrane) (Gogate and Kabadi, 2009; Drakopoupou et al. 2009; Zhou et al. 2015). It is those numerous individual and combined effects that cause the inactivation of microorganisms 

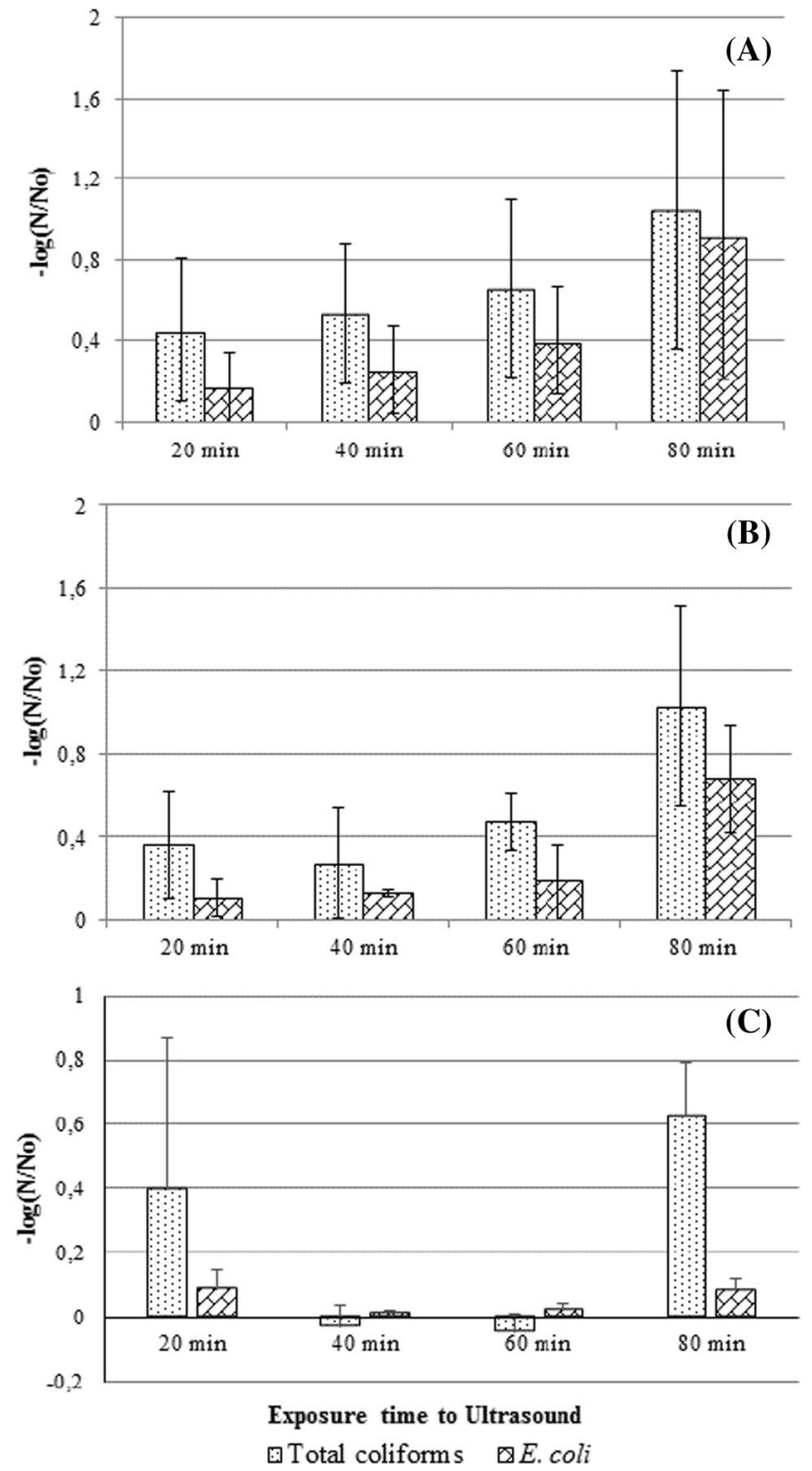

Fig. 1 Effect of exposure time to ultrasound: (A) $25 \mathrm{kHz}$ (STE); (B) $40 \mathrm{kHz}$ (STE) and (C) $40 \mathrm{kHz}$ (AFE) in the inactivation of total coliforms and Escherichia coli

(Nyborg 2001; Mason et al. 2003; Piyasena et al. 2003; Mahamuni e Adewuyi 2010; Zupanc et al. 2019).

The results found for septic tank effluent are similar to the work of Antoniadis et al. 2007 and Hulsmans et al. 2010. Some variables influence the disinfection process with ultrasound: volume and flow applied; appliance power related to the energy released; matrix (water, raw or treated effluent); operation of the treatment unit (batch or continuous); as well as the initial microbial concentration (Hulsmans et al. 2010). In addition, the higher the frequency, the greater the ability to inactivate microorganisms. Still, the result of the ultrasonic effect depends on the constitution of the bacterial cell wall (Gao et al. 2014) and the microorganism (Zupanc
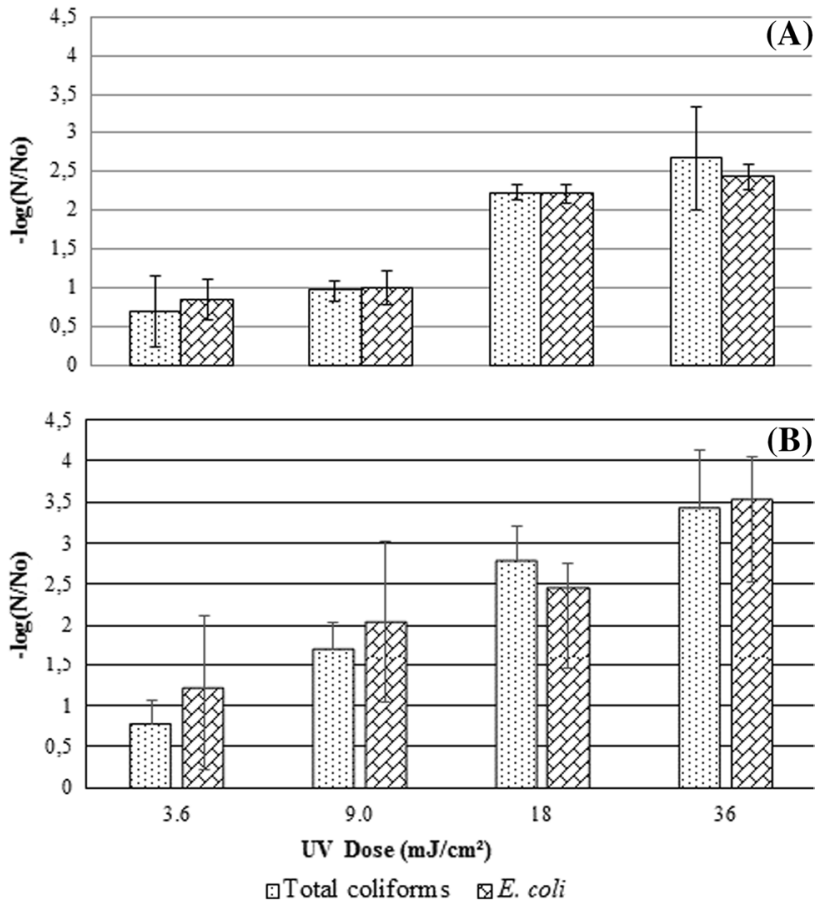

Fig. 2 Inactivation of total coliforms and E. coli as a function of UV doses applied in biologically treated effluent by septic tank (A) and anaerobic filter $(\mathbf{B})$

et al. 2019). The cell walls of gram-negative bacteria (such as E. coli) consist of one or a few layers of peptideoglycan and an outer membrane. The outer membrane of the gramnegative cell consists of lipopolysaccharides, lipoproteins and phospholipids, which makes them more resistant to the process of ultrasonic deactivation. This result was visible, as there was lethal damage to some microorganisms, while others were not affected, and the same time and potency of US was considered.

\section{UV disinfection}

The UV radiation did not change the values of the parameters $\mathrm{pH}$, temperature, $\mathrm{COD}$ and turbidity significantly (Tukey test) (Table S2).

Ultraviolet radiation promoted a reduction greater than $2 \log$ coliforms and E. coli in STE, when doses of 18 and $36 \mathrm{~mJ} \mathrm{~cm}^{-2}$ were applied, which did not differ significantly between them, but differed from the lowest doses analyzed (Tukey test) (Fig. 2). This may be related to the presence of bacterial aggregates and the tail effect in the disinfection process, presenting small inactivation even with dose increase, from 3.6 to $9.0 \mathrm{~mJ} \mathrm{~cm}^{-2}$, and from 18 to $36 \mathrm{~mJ} \mathrm{~cm}^{-2}$ (Gibson et al. 2009; Zhou et al. 2015).

Regarding the best quality effluent-AFE-there was a better performance of ultraviolet radiation, with inactivation close to $3.5 \log$ for both microorganisms, in the highest 
applied dose, a result close to that of Zheng et al (2017), Zhou et al. (2017) and Tan et al. (2017). It is worth mentioning that the doses of 18 and $36 \mathrm{~mJ} \mathrm{~cm}^{-2}$ obtained statistically similar efficiencies (Tukey test).

Turbidity is used to evaluate the performance of UV disinfection. Suspended solids can absorb or disperse UV radiation, as well as serve as protection for microorganisms present in the liquid (Linden and Darby 1998; Zhou et al. 2015). The turbidity presented in the tested effluents can be considered inadequate for the possible indication of disinfection by UV only, and may in fact have influenced the results obtained.

Evaluating the performance of a full-scale ultraviolet disinfection system, studies prove the feasibility of using this method, even in effluent compositions that do not favor the method (Lee et al. 2015; Jackson et al. 2019).

Lee et al. (2015) report that solids negatively influence the efficiency of UV radiation. Although there was no analysis of total solids in this work, turbidity is a parameter that indirectly demonstrates this concentration.

It can be inferred that the best quality effluent resulted in even better efficiency in the UV doses applied with inactivation of the indicator organisms. Similar results are in line with other studies, despite not having ideal conditions of turbidity and COD, but also showing total coliform and E. coli inactivation (Bilotta and Daniel 2012; Medeiros and Daniel, 2015).

It should be noted that UV radiation inactivates microorganisms through the absorption of high-energy light and its action occurs directly on the RNA and DNA of microorganisms, preventing them from reproducing or replicating. However, the recovery of these microorganisms can occur, mainly through a dose considered sublethal of UV radiation (Hijnen et al. 2006; Lee et al. 2015).

\section{Disinfection kinetics}

Chick's applied kinetic model achieved high adherence in both effluents, indicating compliance with first-order kinetics, as reported by Drakopoulou et al. (2009) and Naddeo et al. (2009), for ultrasound; and Carrè et al. (2018), for ultraviolet radiation. Table 2 shows the decay constant $(k)$ and Pearson's correlation coefficient $\left(r^{2}\right)$.

The effect of time corroborates other studies that used ultrasound, which describe that the percentage of death of the analyzed organisms, as well as the levels of changes in molecular structures, increases with the time of exposure (Neis and Blume 2003; Jyoti and Pandit 2004; Gao et al. 2014). The decay constants found, however, were lower than those found by Neis and Blume (2003) and Jin et al. (2013), possibly due to the better effluent characteristics and applied US intensity.

Studies indicate that in addition to the exposure time and the frequency of the ultrasound to which the microorganisms are submitted, it influences inactivation (Antoniadis et al. 2007; Hulsmans et al. 2010). However, this evaluation was not significantly different (between 25 and $40 \mathrm{kHz}$ ) in this present work.

For UV disinfection, the linear correlation, according to the applied dose, was also suggested by Carrè et al. (2018). The concentration of solids, size of biological flakes, turbidity and absorbance values at $254 \mathrm{~nm}$ (Azimi et al. 2013; Schmidtlein et al. 2015; Tan et al. 2017; Carrè et al. 2018), as well as phototransformation and organic micropollutants (Paredes et al. 2018) are determining factors that can explain the best results in AFE in relation to STE.

Table 2 Decay constant and correlation coefficient in disinfection by ultraviolet (UV) and ultrasound (US) radiation

\begin{tabular}{llll}
\hline Disinfectant & Effluent & $k\left(10^{-2} / \mathrm{min}\right)$ & $r^{2}$ \\
\hline US-25 kHz & STE-TC & 2.95 & 0.975 \\
& STE-EC & 2.15 & 0.937 \\
US-40 kHz & STE-TC & 2.47 & 0.930 \\
& STE-EC & 2.67 & 0.952 \\
& AFE-TC & 1.23 & 0.630 \\
& AFE-EC & 1.35 & 0.924 \\
\hline Disinfectant & Effluent & $k\left(\mathrm{~cm}^{2} / \mathrm{mJ}^{2}\right.$ & $r^{2}$ \\
\hline UV-30 W & STE-TC & 30.93 & 0.940 \\
& STE-EC & 29.15 & 0.905 \\
& AFE-TC & 41.59 & 0.924 \\
& AFE-EC & 41.63 & 0.913 \\
\hline
\end{tabular}

TC: total coliforms; EC: E. coli 


\section{Sequential disinfection}

It can be highlighted that the synergistic effect occurred for both microorganisms, being evidenced up to $1 \log$ of inactivation, from the sequential use of the two disinfectants (Table 3), a similar result found by Jin et al. (2013) and Zhou et al. (2015). Hydroxyl radicals produced during cavitation can attack, weaken and disintegrate the chemical structure of the bacterial cell wall (Joyce et al. 2003; Zupanc et al. 2019). In addition, US, used as a primary disinfectant, increases the UV disinfection capacity, especially in wastewater with low transmittance, due to the breakdown of particles and bacterial aggregates (Gibson et al. 2009; Yong et al. 2009; Ayyildiz et al. 2011; Jin et al. 2013; Naddeo et al. 2014). In all cases, microorganisms are eventually exposed to UV radiation more effectively.

Some authors cite the use of ultrasound as a pre-treatment in order to improve posterior disinfection, due to the synergistic effect with chlorine dioxide (Ayyildiz et al. 2011; Naddeo et al. 2014), ultraviolet radiation (Blume and Neis, 2004; Zhou et al. 2015; Naddeo et al. 2014), sodium hypochlorite (Zhou et al. 2016), ozone (Naddeo et al. 2014) or titanium dioxide (Drakopoulou et al. 2009). Thus, with the need for lower doses of disinfectants, it can result in the generation of a lower concentration of disinfection by-products (Zhou et al. 2016).

The results highlight the importance of the concomitant use of US and UV to achieve good inactivation efficiency of microorganisms (Zheng et al. 2017; Annissha et al. 2020). The combination of different disinfectants can be more economically attractive (Neis and Blume, 2003; Mahamuni and Adewuyi, 2010; Hulsmans et al. 2010; Zhou et al. 2016; Gagol et al. 2018) and, in the case of the present study, it may be true due to the application of lower doses of UV and time of exposure to US.

Gram-negative $E$. coli bacteria are more resistant than gram-positive bacteria because their cell wall consists of peptideoglycan and an outer membrane. The outer membrane lipopolysaccharide is a large and complex molecule that contains lipids and carbohydrates. In this work, an inactivation of these bacteria was observed, so that the applied processes (US and UV) were able to break this outer membrane and the UV radiation reached the DNA or RNA of these microorganisms.

It is suggested that the disinfection methods applied in this work to inactivate gram-negative bacteria (E. coli) can also be applied to viruses, since viruses that are more resistant are those that have a shell that protects genetic material (RNA), and this shell consists of lipids, proteins and carbohydrates, as well as the outer membrane of bacteria. Once the RNA of SARS-CoV-2 was found in sewage waters (Ahmed et al. 2020; La Rosa et al. 2020a, b; Randazzo et al. $2020 \mathrm{a}, \mathrm{b})$, there are still no studies on RNA contamination detected in the sewage.

\section{Conclusion}

Despite the low quality of the effluents used, with high turbidity values and COD, the disinfections applied individually were able to reduce the concentration of microorganisms.

Sequential disinfection from the application of US followed by UV is a promising technology, which has achieved synergistic effects greater than $1.0 \mathrm{log}$. Therefore, it may be an indication of a possible real technological application in effluent treatment plants, requiring research to inactivate more resistant microorganisms.

The disinfection of microorganisms was proportional to the time of exposure to ultrasound and the applied UV dose, following Chick's kinetics and, in general, total coliforms were less resistant compared to E. coli, although there was no statistical difference.
Table 3 Synergistic effect after sequential disinfection

\begin{tabular}{lllll}
\hline Microorganism & Effluent (\# test) & $\begin{array}{l}\sum \text { Individual Disin- } \\
\text { fection }(I D)\end{array}$ & $\begin{array}{l}\text { Sequential Disinfec- } \\
\text { tion }(S D)\end{array}$ & Synergism* \\
\hline Total coliforms & STE (1) & 3.25 & 3.58 & 0.32 \\
& STE (2) & 2.47 & 3.28 & 0.81 \\
& STE (3) & 3.74 & 3.77 & 0.03 \\
& AFE (2) & 1.53 & 2.62 & 1.09 \\
E. coli & STE (1) & 2.65 & 3.28 & 0.62 \\
& STE (2) & 2.75 & 3.28 & 0.52 \\
& AFE (1) & 2.12 & 2.25 & 0.12 \\
& AFE (2) & 1.92 & 2.63 & 0.71 \\
\hline
\end{tabular}

Disinfection values and synergism are given as $\log$ values. $*$ Synergism $=$ Observed $S D-(\Sigma I D)$ (USEPA; 1999) 
Supplementary Information The online version contains supplementary material available at https://doi.org/10.1007/s13762-021-03764-7.

Acknowledgements The authors are grateful to Federal University of Santa Maria by the provide of sanitary sewage and the Fundação Nacional de Saúde (FUNASA) for the financial support.

Authors' contribution JSL and EPMJ contributed to conceptualization, data curation, formal analysis, investigation, validation, writing-original draft, writing - review and editing. RCM was involved in conceptualization, project administration, supervision, writing-review and editing. FV and SS contributed to conceptualization, data curation, funding acquisition, methodology, project administration, supervision, writing — original draft, writing — review and editing.

Funding No funding was received for conducting this study. The authors declare they have no financial interests.

Availability of data and material The data that support the findings of this study are available on request from the corresponding author. The data are not publicly available due to privacy or ethical restrictions.

\section{Declarations}

Conflict of interest The authors declare that they have no known competing financial interests or personal relationships that could have appeared to influence the work reported in this paper.

Ethical approval and consent to participate The authors declare ethics approval and consent to participate in this study.

Consent for publication The authors declare that are consent for publication.

\section{References}

Abeledo-Lameiro MJ, Mazás-Ares E, Goméz-Couso H (2018) Use of ultrasound irradiation to inactivate Cryptosporidium parvum oocysts in effluents from municipal wastewater treatment plants. Ultrason Sonochemistry 48:118-126

Ahmed W, Angel N, Edson J et al (2020) First confirmed detection of SARS-CoV-2 in untreated wastewater in Australia: a proof of concept for the wastewater surveillance of COVID-19 in the community. Sci Total Environ 728:138764. https://doi.org/10.1016/j. scitotenv.2020.138764

Annisha ODR, Li Z, Zhou X, Stenay Jr NMD, Donde OO (2020) Performance evaluation of combined ultravioleta-ultrasonic Technologies in removal of sulfonamide and tetracycline resistant Escherichia coli from domestic effluents. J Water Sanit Hyg Dev, in press

Antoniadis A, Poulios I, Nikolakaki E, Mantzavinos D (2007) Sonochemical disinfection of municipal wastewater. J Hazard Mater 146:492-495

APHA, WEF, AWWA (2012) Standard methods for the examination of water and wastewater. 22nd edition

Ayyildiz O, Sanik S, Ileri B (2011) Effect of ultrasonic pretreatment on chlorine dioxide disinfection efficiency. Ultrason Sonochemistry 18:683-688

Azimi Y, Chen X, Allen DG, Pileggi V, Seto P, Droppo IG, Farnood RR (2013) UV Disinfection of wastewater flocs: the effect of secondary treatment conditions. Water Sci Technol 67(12):2719-2723
Bagluglia CM, Mininni G, Gianico A (2008) Is sonication effective to improve biogas production and solids reduction in excess sludge digestion? Water Sci Tecnol 57(4):479-483

Billota P, Daniel LA (2012) Utilização de lâmpadas germicidas na desinfecção de esgoto sanitário. Rev Ambiente Água 7(1):120-129

Blume T, Neis U (2004) Improved wastewater disinfection by ultrasound pre-treatment. Ultrasounds Sonochemistry 11(5):333-336

Bosshard F, Riedel K, Schneider T, Geiser C, Bucheli M, Egli T (2010) Protein oxidation and aggregation in UVA-irradiated Escherichia coli cells as signs of accelerated cellular senescence. Environ Micrbiol 12(11):2931-2945

Carrè E, Pérot J, Jauzein V, Lopez-Ferber M (2018) Impact of suspended particles on UV disinfection of activated-sludge effluent with the aim of reclamation. J Water Process Eng 22:87-93

Chick H (1908) An investigation of the laws of disinfection. J Hyg $8(1): 92-158$

Dehghani MH, Zarei A, Yousefi M (2019) Efficiency of ultrasound for degradation of an anionic surfactant from water: Surfactant determination using methylene blue active substances method. MethodsX 6:805-814

Drakopoulou S, Terzakis S, Fountoulakis MS, Mantzavinos D, Manios $\mathrm{T}$ (2009) Ultrasound-induced inactivation of gram-negative and gram-positive bacteria in secondary treated municipal wastewater. Ultrason Sonochemistry 16:629-634

Farrell C, Hassard F, Jefferson B, Leziart T, Nocker A, Jarvis P (2018) Turbidity composition and the relationship with microbial attachment and UV inactivation efficacy. Sci Total Environ 624:638-647

Gagol M, Przyjazny A, Boczkaj G (2018) Wastewater treatment by means of advanced oxidation process based on cavitation-A review. Chem Eng J 338:599-627

Gao S, Lewis GD, Ashokkumar M, Hemar Y (2014) Inactivation of microorganisms by low-frequency high-power ultrasound: 1 . Effect of growth phase and capsule properties of the bacteria. Ultrason Sonochemistry 21:446-453

Gibson JH, Yong DHN, Farnood RR, Seto P (2008) A literature review of ultrasound technology and its application in wastewater disinfection. Water Qual Res J Can 43(1):23-35

Gibson JH, Hon H, Farnood R, Droppo IG, Seto P (2009) Effects of ultrasound on suspended particles in municipal wastewater. Water Res 43:2251-2259

Gogate PR, Kabadi AM (2009) A review of applications of cavitation in biochemical engineering/biotechnology. Biochem Eng J 44:60-72

Hallmich C, Gehr R (2010) Effect of pre- and post-UV disinfection conditions on photoreactivation of fecal coliforms in wastewater effluents. Water Res 44(9):2885-2893

Hijnen WAM, Beerendonk EF, Medema GJ (2006) Inactivation credit of UV radiation for viruses, bacteria and protozoan (oo)cysts in water: a review. Water Res 40(1):3-22

Hulsmans A, Joris K, Lambert N, Rediers H, Declerck P, Delaedt Y, Ollevier F, Liers S (2010) Evaluation of process parameters of ultrasonic treatment of bacterial suspensions in a pilot scale water disinfection system. Ultrason Sonochemistry 17:1004-1009

Jackson MR, Meschke JS, Simmons J, Isaksen TB (2019) Fecal coliform concentrations in effluent from ultraviolet disinfection units installed in onsite wastewater treatment systems. J Water Health 17(1):113-123

Jin X, Li Z, Xie L, Xhao Y, Wang T (2013) Synergistic effect of ultrasonic pre-treatment combined with UV irradiation for secondary effluent disinfection. Ultrason Sonochemistry 20(6):1384-1389

Joyce E, Phull SS, Lorimer JP (2003) The development and evaluation of ultrasound for the treatment of bacterial suspensions. A study of frequency, power and sonication time on cultured Bacillus species. Ultrasounds Sonochemistry 10(4-5):315-318 
Joyce E, Al-Hashimi A, Mason TJ (2011) Assessing the effect of different ultrasonic frequencies on bacterial viability using flow cytometry. J Appl Microbiol N 110(4):862-870

Jyoti KK, Pandit AB (2004) Effect of cavitation on chemical disinfection efficiency. Ultrason Sonochemistry 38:2249-2258

Kokkinos P, Mandilara G, Nikolaidou A, Velegraki A, Theodoratos P, Kampa D, Blougoura A, Christopoulou A, Smeti E, Kamizoulis G, Vantarakis A, Mavridou A (2015) Performance of three smallscale wastewater treatment plants. A challenge for possible reuse. Environ Sci Pollut Res 22:17744-17752

La Rosa G, Iaconelli M, Mancini P et al (2020a) First detection of SARS-CoV-2 in untreated wastewaters in Italy. Sci Total Environ 736:139652. https://doi.org/10.1016/j.scitotenv.2020.139652

La Rosa G, Iaconelli M, Mancini P, Bonanno Ferraro G, Veneri C, Bonadonna L, Lucentini L, Suffredini E (2020b) First detection of SARS-CoV-2 in untreated wastewaters in Italy. Sci Total Environ 736:139652

Lee O, Kim HY, Park W, Kim T, Yu S (2015) A comparative study of disinfection efficiency and regrowth control of microorganism in secondary wastewater effluent using UV, ozone, and ionizing irradiation process. J Hazard Mater 295:201-208

Liang Y, Zhang Z, Yang X, Liu W (2013) Effect of suspended solids on the sequential disinfection of secondary effluent by UV irradiation and chlorination. J Environ Eng 139:1482-1487

Linden KG, Darby JL (1998) Ultraviolet disinfection of marginal effluents: determining ultraviolet absorbance and subsequent estimation of ultraviolet intensity. Water Environ Res 70(2):214-223

Mahamuni NN, Adewuyi YG (2010) Advanced oxidation processes (AOPs) involving ultrasound for waste water treatment: a review with emphasis on cost estimation. Ultrason Sonochemistry 17:990-1003

Mason TJ, Joyce E, Phull SS, Lorimer JP (2003) Potential uses of ultrasound in the biological decontamination of water. Ultrason Sonochemistry 10:319-323

Medeiros RC, Daniel LA (2015) Study of sequential disinfection for the inactivation of protozoa and indicator microorganisms in wastewater. Acta Sci Technol 37(2):203-209

Naddeo V, Landia M, Belgiorno V (2009) Wastewater disinfection by combination of ultrasound and ultraviolet irradiation. J Hazard Mater 168(2-3):925-929

Naddeo V, Cesaro A, Mantzavinos D, Fatta-Kassinos D, Belgiorno V (2014) Water and wastewater disinfection by ultrasound irradiation-a critical review. Globalnest 16(3):561-577

Neis U, Blume T (2003) Ultrasonic disinfection of wastewater effluents for high-quality reuse. Water Sci Technol Water Supply 3(4):261-267

Nyborg WL (2001) Biological effects of ultrasound: development of safety guidelines. Part II: general review. Ultrasound Med Biol 27(3):301-333

O'Flaherty E, Membré J, Cummins E (2017) Meta-analysis of the reduction of antibiotic-sensitive and antibiotic-resistant Escherichia coli as a result of low- and medium-pressure UV lamps. Water Sci Technol Bonus Issue 2:612-620

Oller I, Malato S, Sánchez-Pérez JA (2011) Combination of advanced oxidation processes and biological treatments for wastewater decontamination-A review. Sci Total Environ 409:4141-4166

Olvera M, Eguía A, Rodríguez O, Chong E, Pillai SD, Ilangovan K (2008) Inactivation of Cryptosporidium parvum oocysts in water using ultrasonic treatment. Bioresour Technol 99:2046-2049

Paiva RFPS, Souza MFP (2018) Associação entre condições socioeconômicas, sanitárias e de atenção básica e a morbidade hospitalar por doenças de veiculação hídrica no Brasil. Cadernos de Saúde Pública (Online), 34(1):e00017316. tab

Paredes L, Omil F, Lema JM, Carballa M (2018) What happens with organic micropollutants during UV disinfection in WWTPs? A global perspective from laboratory to full-scale. J Hazard Mater 342:670-678
Piyasena P, Mohareb E, Mckellar RC (2003) Inactivation of microbes using ultrasound: a review. Int J Food Microbiol 87:207-216

Randazzo W, Truchado P, Cuevas-Ferrando E et al (2020a) SARSCoV-2 RNA in wastewater anticipated COVID-19 occurrence in a low prevalence area. Water Res 1-33. https://doi.org/10.1016/j. watres.2020.115942

Randazzo W, Truchado P, Cuevas-Ferrando E, Simón P, Allende A, Sánchez G (2020b) SARS-CoV-2 RNA in wastewater anticipated COVID-19 occurrence in a low prevalence area. Water Res 181

Schmidtlein F, Lubken M, Grote I, Orth H, Wichern M (2015) Photoreactivation and subsequent solar disinfection of Escherichia coli in UV-disinfected municipal wastewater under natural conditions. Water Sci Technol 71(2):220-226

Siqueira MS, Rosa RS, Bordin R, Nugem RC (2017) Internações por doenças relacionadas ao saneamento ambiental inadequado na rede pública de saúde da região metropolitana de Porto Alegre, Rio Grande do Sul, 2010-214. Epidemiol e Serviços De Saúde 26(4):795-806

SNIS (2019) Sistema Nacional de Informação sobre Saneamento. $24^{\circ}$ Diagnóstico dos serviços de água e esgoto - 2018. Brasília. Ministério do Desenvolvimento Regional. Secretaria Nacional de Saneamento, 180p.

Tan TC, Azimi Y, Farnood R (2017) Tailing propensity in the ultraviolet disinfection of trickling filter and activated sludge wastewater treatment processes. Water Sci Technol 76(3):623-632

USEPA (1999) United States Environmental Protection Agency. Alternative Disinfectants and Oxidants Guidance Manual. Environmental Protection Agency, Washington, DC, USA

USEPA (2012) United States Environmental Protection Agency. Guidelines for water reuse: EPA/600R-12/618

Vázquez-López M, Amabilis-Sosa LE, Moeller-Chávez GE, Roé-Sosa A, Neumann P, Vidal G (2018) Evaluation of the ultrasound effect on treated municipal wastewater. Environ Technol 40:3568-3577

Wang X, Hu X, Wang H, Hu C (2012) Synergistic effect of the sequential use of UV irradiation and chlorine to disinfect reclaimed water. Water Res 46:1225-1232

WHO (2006) Guidelines for safe use of wastewater, excreta and graywater. World Health Organization

Yong HN, Farnood RR, Cairns W, Mao T (2009) Effect of sonication on UV disinfectability of primary effluents. Water Environ Res 81(7):695-701

Zhang SH, Wu CD, Jin HZ (2007) Experimental study of ultrasound collaborating co-action on controlling E.coliform's photoreactivation after ultraviolet disinfection in wastewater treatment plant. Tech Acoust 26(6): 1168-1171

Zheng J, Su C, Zhou J, Xu L, Qian Y, Chen H (2017) Effects and mechanisms of ultraviolet, chlorination, and ozone disinfection on antibiotic resistence genes in secondary effluents of municipal wastewater treatment plants. Chem Eng J 317:309-316

Zhou X, Guo H, Li Z, Zhao J, Yun Y (2015) Experimental study on the disinfection efficiencies of a continuous-flow ultrassound/utraviolet baffled reactor. Ultrason Sonochemistry 27:81-86

Zhou X, Zhao J, Li Z, Song J, Li X, Yang X, Wang D (2016) Ehancement effects of ultrasound on secondary wastewater effluent disinfection by sodium hypochlorite and disinfection by-products analysis. Ultrason Sonochemistry 29:60-66

Zhou X, Li Z, Yan Y, Yin J (2017) Disinfection effect of a continuousflow ultrasound/ultraviolet baffled reactor at a pilot scale. Ultrason Sonochemistry 37:114-119

Zupanc M, Pandur Z, Perdih TS, Stopar D, Petkovsek M, Dular MA (2019) Effects of cavitation on different microorganisms: the current understanding of the mechanisms taking place behid the phenomenon. A review and proposals for further research. Ultrason Sonochemistry 57:147-165 